DOI https://doi.org/10.36059/978-966-397-117-9/141-158

\title{
THE PROBLEMS OF LEGAL REGULATION OF HUMAN RIGHTS AND FREEDOMS AT TEMPORARILY OCCUPIED TERRITORIES OF UKRAINE
}

\section{Iliashko O. O.}

\section{INTRODUCTION}

In the recent years constitutional human rights at the temporarily occupied territories have been in focus of lawyers and law scientists as well as the scientists of other branches of socio-humanitarian sciences. The interest in the subject of the present research is expressed through significance of functions performed by constitutional human rights at the temporarily occupied territories of Ukraine under the modern conditions.

The research of constitutional human rights nature at the occupied territories can be divided into types of knowledge according to subject belonging, as a result the sources of philosophical, theoretical as well as branch, inter-branch and applied orientation can be distinguished. In every individual case a scientist solves own research tasks based on peculiarities of the subject and the method of the research. However, they constitute a holistic, but diverse picture of one of constitutional human and civil rights and freedoms as a whole.

To establish inter-branch connections between individual types of scientific knowledge to use it effectively, to overcome inconsistency and gaps in research of certain aspects of constitutional human rights and freedoms at the temporarily occupied territories, one should strengthen a philosophical and methodological basis of scientific research, pay attention to the problems of understanding the phenomena essence, their legal nature, establishing the cause and effect relations, revealing the degree of possible and necessary in subjective right, determining criteria for determination of limits for freedom and justice.

In Ukraine the development of protection institution for constitutional human and civil rights and freedoms at the temporarily occupied territories is taking place in the context of global genesis of these rights and freedoms. For all the time constitutional human rights and freedoms at the temporarily occupied territories of Ukraine have been 
enriched with positive achievements of international standards in the field of human rights. Taking into account sad events of 2014, Ukraine based on its historical experience and international experience builds up effective mechanisms of human rights protection at the temporarily occupied territories.

Taking into account significance of the institute for human rights protection at the temporarily occupied territories not only for Ukraine, but for all international community, it can be considered in two aspects:

1) As a legally separated set of legal norms governing constitutional relations in the field of human rights provision at the temporarily occupied territories;

2) A combination of legal ways and means for effective consolidation, provision, protection and exercise of human rights and freedoms at the temporarily occupied territories by special authorized state and international institutions implementing law policy in the field of human rights provision.

\section{General State of Human Rights and Freedoms at the Temporarily Occupied Territories of Ukraine}

The events of recent years in and around our country, the analysis of a national system of law shows that there are a number of urgent problems regarding the fundamental national values declared in the Constitution of Ukraine such as human life, health and safety, human rights and freedoms, the state and social order of the country, its sovereignty and territorial integrity, the development of a law-governed, democratic, and social state. All these problems have been manifested more clearly under the conditions of temporary seizure of part of Ukrainian lands by the Russian Federation. Therefore, the scientific awareness of the problems of constitutional human and civil rights and freedoms at the occupied territories of Ukraine is very urgent.

The list of human and civil rights and freedoms, enshrined in the Constitution and other legislation of Ukraine, is universally recognized for any law-governed state. The main problem is proper provision of their implementation, creation of effective state mechanisms for their protection. The achievement of this goal is complicated in those countries where socio-political and legal systems undergo significant transformations. The main object, to which radical economic, political, 
social and spiritual transformations in our country are directed and determined by the strategic course of integration into the European and world democratic community, is a person, human interests, rights and freedoms.

The Constitution of Ukraine proclaimed the establishment and provision of human rights and freedoms as a main duty of the state and laid the basis for construction of such mechanism. Human rights and freedoms at the temporarily occupied territories of Ukraine are an integral part of the system of constitutional human and civil rights and freedoms.

Democratic transformations in all fields of society life require improvement of a legal system of Ukraine, its constitutional foundations as the legal basis for the systematic structural and organizational reform of public power, the system of state management, the establishment of priority national values, and the creation of a mechanism for the protection of human rights and freedoms. The need to clarify the problems, trends and prospects of the development of modern state studies also emphasizes the necessity for detailed comprehensive development of fundamental legal issues. An important task of modern historical science and jurisprudence is the substantial revision of the content, rethinking of national state-legal reality in the context of generally recognized democratic principles of functioning of the social and law-governed state, the development of a powerful tool for the provision and protection of human rights and freedoms ${ }^{1}$.

Therefore, the priority of human interests, rights and freedoms has determined actualization of the need for legal provision of development in the humanitarian field. This is, first of all, the guarantee of fundamental human rights: to the safety of life, freedom and personal inviolability; to health and medical care; to free development of personality, respect for honor and dignity; for work and rest, social protection; to the freedom of creativity in all domains - social, scientific, technical, artistic, etc. It follows from here that creation of a law-governed society where the supremacy of law prevails, and human rights are desired, indisputable and guaranteed is the precondition for the formation of a democratic, lawgoverned, and social state. And only when human rights become existing reality, namely, the urgent need of every person, an integral feature of

\footnotetext{
1 Правова система України: історія, стан та перспективи : у 5 т. Х. : Право, 2008. - Т. 2 : Конституційні засади правової системи України і проблеми її вдосконалення / за заг. ред. Ю. П. Битяка. Х. : Право, 2008. 576 c.
} 
their sense of justice, a factor of the attitude to environment of both individual person and power institutions and its bodies, a truly lawgoverned state can be built. Therefore, the main condition for the functioning of civil society and law-governed state is precisely a person, a personality who embodies his/her right to self-fulfillment. And then the personality as a subject of a law-governed society and state becomes such a citizen having a sense of civic responsibility and real patriotism.

So, a person and human rights are a priority among all humanitarian values. And this priority, as well as their role and purpose, are obvious and undoubted. Any social reform, development and implementation of any state programs, planning and implementation of large-scale and smaller projects should be correlated with the "human dimension", and in this very context we should evaluate everything that is happening in our state and in the world in general today.

At present, the constitutional and legal regulation of relations connected with the temporary occupation of certain territories is a very important issue for Ukraine in the context of the hybrid war that the Russian Federation is leading against us, which occupied parts of Ukrainian lands in 2014. Ukraine, mobilizing its forces and with the support of a progressive international community, is struggling to restore its territorial integrity.

In general, the problems of regulation of temporarily occupied territories have been the subject of research attention since ancient times. The first attempt to link geographic conditions with the character and customs of people, their economic and political system was carried out by French philosopher of the $18^{\text {th }}$ century Montesquieu. Such scholars of the $19^{\text {th }}$ century as the English historian H. Buckle, the French geographer E. Reclus, the American geographer E. Huntington, the Russian geographer and sociologist L. Mechnikov at al. developed such problems.

The founder of geographical determinism is the German geographer, ethnologist, sociologist, founder of anthropogeography, geopolitics, the theory of diffusion and political geography Friedrich Ratzel (1844-1904). His main merit is the discovery of links between policies of a particular country and its geographical location. In his book "Political Geography" (1897), he emphasizes on the political and geographical location of the state. 
The clarification of patterns of spatial location of settlements and creation of geographic models of cities (geo-social studies) began in the first half of the $20^{\text {th }}$ century. One of the first "model-makers" of city geography was V. P. Semenov-Tian-Shansky. Geographical aspects in the context of the economy placement were developed by German scholars who created the so-called theory of a standort - a place of location. The term "standort" means not real, but optimal placement of production. This direction was represented by J. Thunen, A. Weber, A. Losch and others.

In national geographic science, S. L. Rudnytsky was one of the first who examined the particular influence of a geographical position on the development of Ukraine in 1916 in the work "Ukrainian case on the state of political geography"2. A significant contribution to the development of category "geographical position" was made by O. Topchiev, O. Shabliy, M. Palamarchuk, M. Pistun, V. Grytsevich, V. Lazhnik and others. Thus, the features of the state territory have a great impact on its significance at the world political arena, and the concept of "geographical location" is one of the fundamental categories of geography.

The formation of Ukraine as an independent state is accompanied by transformation processes, requiring diverse research. In this sense, the political and geographical factor allows localizing the advantages and threats spatially, finding out the regional proportions and disproportions of the political field of the state, as well as determining the direction of development of political processes.

This research corresponds to the state scientific programs, plans and topics, which comprehensively cover the human and civil rights and freedoms at the temporarily occupied territories. This is, first of all: the Law of Ukraine of July 11, 2001 "On Priority Areas for the Development of Science and Technology" (Article 3, Priority Areas for the Development of Science and Technology for the Period up to 2020); "The National Program of Adaptation of Ukrainian Legislation to the Law of the European Union" (the Law of Ukraine of March 18, 2004, № 1629-IV); "Priority Direction of the Development of Legal Science for 2016-2020", approved by the Resolution of the General Meeting of the National Academy of Legal Sciences of Ukraine dated March 3, 2016, "Strategy for Sustainable Development "Ukraine-2020", approved by the

\footnotetext{
$282 \mathrm{c}$.

${ }^{2}$ Рудницький С. Л. Українська справа зі становища політичної географії. Берлін: Укр. Слово, 1923.
} 
Decree of the President of Ukraine dated January 12, 2015 №. 5/2015, "The Plan of Legislative Provision of the Reform in Ukraine", approved by the Verkhovna Rada of Ukraine on June 4, 2015 № 509-VIII.

\section{The Concept and Features of "Temporarily Occupied Territory of Ukraine" and Its Legal Regime}

Yet at the beginning of the $20^{\text {th }}$ century, S. Rudnitsky ${ }^{3}$, defining the role of political geography in the system of geographical sciences and laying the foundation of national political geography, noted that "the functioning of the state always depended on its place in the system of world territorial-political relations and the regional distribution of internal political forces". By this fact he emphasized the significance of spatial analysis of political processes.

The state border is, above all, the frontier of protecting its national and international interests: economic, political, social, military, environmental and others. In addition, it is a face, a reputation of the state. For the young Ukrainian statehood, when the processes of forming national identity are taking place in the country, the feeling of own nation is manifested, first of all, through contacts with the outside world, which is the most visual at the border. The border is also a symbol of national sovereignty, independence of the state ${ }^{4}$.

However, since 2014, a part of Ukrainian territory has been under the threat of exclusion - occupation and annexation of Ukrainian lands of the Autonomous Republic of Crimea by the Russian Federation took place.

The concept of "military occupation" (Latin occupatio - seizure) is defined as the temporary seizure by the armed forces of one state of the territory of another state without gaining sovereignty over it. Currently, there is no consensus among experts on how to determine the set of criteria by which one can determine the correspondence of a particular occupation case unambiguously. In various sources, the following features of occupation are mentioned: temporality of the mission, temporary status (we should mention that the limits of temporality, clear criteria for the distinction from continuity are not given); the inevitable presence of the victim state (country, people, etc.) as a party to the relations;

\footnotetext{
${ }^{3}$ Рудницький С. Л. Українська справа зі становища політичної географії. Берлін: Укр. Слово, 1923. $282 \mathrm{c}$.

${ }^{4}$ Купрієнко Д. А., Дем’янюк Ю. А., Діденко О. В. Державна територія і державний кордон: навчальний посібник. Хмельницький: Видавництво НАДПСУ, 2014. 256 с.
} 
indispensable - de jure or de facto - staying in a state of war, or violent nature of invasion of the occupation armed forces; taking over the functions of management, establishment of own administration at the occupied territory, establishment of the fact of control over the occupied territory and/or the population by armed forces; compliance with international legal norms, which determine the compulsory international legal responsibility for its initiator; recognition of the occupational status of the territory by the world community.

Taking into account the abovementioned, one can make a conclusion that occupation in all cases is carried out with the participation of military force and has some types: occupation under the state of war (military, hostile); post-war occupation (according to peace treaties) ${ }^{5}$.

Occupation under the state of war. The regime and legal aspects of military occupation are defined by the special international treaties adopted by the IV Hague Conference of 1907, the Geneva Conventions of 1949 and the protocols of 1977 to them. According to these international acts, military occupation is the temporary occupation by the armed forces of one state of the territory of another state with the taking over of the basic management functions. This territory is considered occupied when the actual power on it passed to the hostile army. The occupying party must respect human rights, prevent deportations and mass executions of population. It has the right to withdraw funds, treasury and other state assets of the occupied party, while private property, community property, as well as educational, scientific, religious, artistic, charitable institutions should be inviolable.

Armed resistance in case of occupation is not a decisive factor. The Geneva Conventions of 1949 (Article 2) state: "The Convention will also apply in all cases of occupation of all or a part of the territory of the High Contracting Party, even if this occupation does not meet any armed resistance".

Post-war occupation. The regime and legal rules of post-war occupation are usually determined by special international treaties of stakeholders specifically for a particular country or territory for the purpose of fulfilling the terms of a peace treaty, for example, in the event of imposing an indemnity. The post-war occupation is also aimed at

\footnotetext{
5 Купрієнко Д. А., Дем’янюк Ю. А., Діденко О. В. Державна територія і державний кордон: навчальний посібник. Хмельницький: Видавництво НАДПСУ, 2014. 256 с.
} 
threatening or reprisals, such as an embargo or a boycott, to force the other party to take necessary action ${ }^{6}$.

Occupation in peace time. Occupation is not always connected with war. The regime and legal norms of non-hostile occupation in peace time, as well as in the post-war period, are established by special treaties between states. However, there is still no generally accepted view on sufficiency for inclusion in this category of bilateral treaties between the occupier state and the occupied state, whether the indispensable condition is the verification and recognition of such treaties or a direct mandate from the world community, its supranational structures such as the League of Nations, the United Nations. Non-hostile occupations include, as a rule, numerous peacekeeping missions of the UN, NATO, Collective Security Treaty Organization (CSTO) and other organizations in the event of presence of a UN mandate. The issues of permissible levels of interference or non-interference of the occupation forces with the activities of political power at the occupied territory are considered as essential ${ }^{7}$.

At present, Ukrainian legislation, in particular the Law of Ukraine "On ensuring the rights and freedoms of citizens and legal regime at the temporarily occupied territory of Ukraine" (Article 1), has determined that the temporarily occupied territory of Ukraine is an integral part of the territory of Ukraine, governed by its Constitution and laws.

The temporarily occupied territories of Ukraine are recognized as follows:

1) The land of the Autonomous Republic of Crimea and Sevastopol, internal waters of Ukraine of these territories;

2) Internal sea waters and the territorial sea of Ukraine around the Crimean Peninsula, the territory of the exclusive (maritime) economic zone of Ukraine along the coast of the Crimean Peninsula and the coastal continental shelf of Ukraine, which is subject to jurisdiction of Ukrainian state authorities in accordance with norms of international law, the Constitution and laws Ukraine;

\footnotetext{
${ }^{6}$ Купрієнко Д. А., Дем’янюк Ю. А., Діденко О. В. Державна територія і державний кордон: навчальний посібник. Хмельницький: Видавництво НАДПСУ, 2014. 256 с.

${ }^{7}$ Купрієнко Д. А., Дем'янюк Ю. А., Діденко О. В. Державна територія і державний кордон: навчальний посібник. Хмельницький: Видавництво НАДПСУ, 2014. 256 с.
} 

part $^{8}$.

3) Airspace over the territories specified in clause 1 and 2 of this

Normative legal regulation of the occupied territory is carried out by the Constitution of Ukraine, the Law of Ukraine "On ensuring the rights and freedoms of citizens and the legal regime at the temporarily occupied territory of Ukraine", the Law of Ukraine "On Border Control", the Criminal Code of Ukraine (Articles 332-1, 438), the Criminal Procedural Code of Ukraine, the Code of Administrative Offences of Ukraine (Articles 202, 204-2), the Order of the Cabinet of Ministers of Ukraine "On Temporary closure of checkpoints across the state border and control points" and others.

Temporarily occupied territories are subject to a special legal regime of crossing their borders, transactions, elections and referendums, the exercise of other human rights and freedoms. The legal regime of the temporarily occupied territory also includes a special procedure for ensuring the rights and freedoms of people who live there. This regime can be determined, changed or canceled solely by the laws of Ukraine?.

The Basic Law of Ukraine has determined that Ukraine is a sovereign and independent, democratic, social, law-governed state which sovereignty extends over its entire territory. Ukraine is a unitary state, and its territory within the boundaries of the existing border is integral and inviolable ${ }^{10}$.

The Russian Federation cynically violated these provisions of the Constitution of Ukraine, having infringed on the territorial integrity of Ukraine.

The Constitution of Ukraine (Article 17) defines: protection of the sovereignty and territorial integrity of Ukraine, ensuring its economic and information safety are the most important functions of the state, the matter of all Ukrainian people. The defense of Ukraine, protection of its sovereignty, territorial integrity and inviolability are relied on the Armed Forces of Ukraine.

\footnotetext{
${ }^{8}$ Про забезпечення прав і свобод громадян та правовий режим на тимчасово окупованій території України: Закон України від 27.04.2014 р. № 1207-VII. Дата оновлення: 04.11.2018 p. URL: https://zakon.rada.gov.ua/laws/show/1207-vii

9 Про забезпечення прав і свобод громадян та правовий режим на тимчасово окупованій території України: Закон України від 27.04.2014 р. № 1207-VII. Дата оновлення: 04.11.2018 p. URL: https://zakon.rada.gov.ua/laws/show/1207-vii

10 Конституція України: Закон України від 28.06.1996 р. № 254к/96-ВР. Дата оновлення: 21.02.2019 p. URL: http://zakon2.rada.gov.ua/laws/show/254к/96-вр.
} 
The maintenance of state security and protection of the state border of Ukraine are entrusted to corresponding military formations and lawenforcement bodies of the state, organization and procedure of their activities are determined by law. The Armed Forces of Ukraine and other military formations can be used by no one to restrict the rights and freedoms of citizens or in order to overthrow the constitutional order, eliminate the authorities or hinder their activities ${ }^{11}$.

The activities of Ukraine in the foreign policy domain are aimed at ensuring its national interests and safety by maintaining peaceful and mutually beneficial cooperation with the members of international community on generally accepted principles and in compliance with the norms of international law ${ }^{12}$.

The Constitution of Ukraine (section 2) also defines the rights, freedoms and duties of a person and a citizen, extending throughout the territory of the state. Occupation limited the ability of people at the temporarily occupied territories to exercise the rights provided by this section.

The territorial structure of Ukraine is based on the principles of unity and integrity of the state territory, a combination of centralization and decentralization in the exercise of powers, balance and socio-economic development of regions, taking into account their historical, economic, ecological, geographical and demographic peculiarities, ethnic and cultural traditions.

The administrative-territorial structure of our state (Article 133 of the Constitution of Ukraine) include the Autonomous Republic of Crimea, regions, districts, cities, districts in cities, settlements and villages. Kyiv and Sevastopol have a special status, defined by the laws of Ukraine ${ }^{13}$.

Since 2014, the system of administrative-territorial organization of Ukraine has been violated, due to the loss of actual control over the Autonomous Republic of Crimea, part of the territories of Donetsk and Luhansk regions.

The status of the Autonomous Republic of Crimea is defined in section 10 of the Constitution of Ukraine, Article 134 of which states that

11 Конституція України: Закон України від 28.06.1996 р. № 254к/96-ВР. Дата оновлення: 21.02.2019 p. URL: http://zakon2.rada.gov.ua/laws/show/254к/96-вр.

12 Конституція України: Закон України від 28.06.1996 p. № 254к/96-ВР. Дата оновлення: 21.02.2019 p. URL: http://zakon2.rada.gov.ua/laws/show/254к/96-вр.

13 Конституція України: Закон України від 28.06.1996 p. № 254к/96-ВР. Дата оновлення: 21.02.2019 p. URL: http://zakon2.rada.gov.ua/laws/show/254к/96-вр. 
the Autonomous Republic of Crimea is an integral part of Ukraine and, within the limits of powers defined by the Constitution of Ukraine, resolves the issues assigned to its competence ${ }^{14}$. According to Article 135 The Autonomous Republic of Crimea has its Constitution adopted by the Verkhovna Rada of the Autonomous Republic of Crimea and approved by the Verkhovna Rada of Ukraine in not less than half of its constitutional composition.

At the same time, the normative legal acts of the Verkhovna Rada of the Autonomous Republic of Crimea and the decisions of its Council of Ministers should not contradict the Constitution and laws of Ukraine. They are adopted in accordance with the Constitution of Ukraine, the laws of Ukraine, acts of the President of Ukraine and the Cabinet of Ministers of Ukraine and for their implementation ${ }^{15}$.

The representative body of the ARC (Article 136 of the Constitution of Ukraine) is the Verkhovna Rada of the Autonomous Republic of Crimea, whose deputies are elected on the basis of universal, equal, direct electoral right by secret ballot. The term of powers of the Verkhovna Rada of the ARC, whose deputies are elected at the regular election, is five years. Terminating the powers of the Verkhovna Rada of the ARC entails the termination of powers of its deputies. The Verkhovna Rada of the Autonomous Republic of Crimea, within the scope of its powers, makes decisions and resolutions that are compulsory for implementation in the Autonomous Republic of Crimea. The Crimean government is the Council of Ministers of the Autonomous Republic of Crimea. The chairman of the Council of Ministers of the ARC is appointed and dismissed by the Verkhovna Rada of the Autonomous Republic of Crimea with the consent of the President of Ukraine. The powers, procedure for the formation and activities of the Verkhovna Rada and the Council of Ministers of the ARC are determined by the Constitution and laws of Ukraine, normative legal acts of the Verkhovna Rada of the ARC on matters within its competence. Justice in the Autonomous Republic of Crimea is carried out by the courts of Ukraine ${ }^{16}$.

14 Конституція України: Закон України від 28.06.1996 р. № 254к/96-ВР. Дата оновлення: 21.02.2019 p. URL: http://zakon2.rada.gov.ua/laws/show/254к/96-вр.

15 Конституція України: Закон України від 28.06.1996 р. № 254к/96-ВР. Дата оновлення: 21.02.2019 p. URL: http://zakon2.rada.gov.ua/laws/show/254к/96-вр.

16 Конституція України: Закон України від 28.06.1996 р. № 254к/96-ВР.Дата оновлення: 21.02.2019 p. URL: http://zakon2.rada.gov.ua/laws/show/254к/96-вр. 
Article 137 of the Constitution of Ukraine stipulates that the ARC carries out normative regulation of the following issues:

1) Agriculture and forests;

2) Melioration and quarries;

3) Public works, crafts and trading; charity;

4) Urban development and housing;

5) Tourism and hotel business; fairs;

6) Museums, libraries, theaters and other cultural institutions, historical and cultural reserves;

7) Public transport, highways, water pipes;

8) Hunting and fishing;

9) Sanitary and hospital services.

In case of non-compliance of normative legal acts of the Verkhovna Rada of the ARC with the Constitution of Ukraine and the laws of Ukraine, the President of Ukraine may suspend their action with simultaneous appeal to the Constitutional Court of Ukraine as to their constitutionality ${ }^{17}$.

The competence of the ARC includes (Article 138 of the Constitution):

1) Appointment of the election of deputies of the Verkhovna Rada and approval of the ARC election commission composition;

2) Organization and conduct of local referendums;

3) Management of property belonging to the Autonomous Republic of Crimea;

4) Development, approval and implementation of the ARC budget on the basis of a unified tax and budget policy of Ukraine;

5) Development, approval and implementation of the ARC programs regarding socio-economic and cultural development, rational use of nature, environmental protection in accordance with national programs;

6) Determination of the status of localities as resorts; establishment of sanitary protection zones of resorts;

7) Participation in ensuring the rights and freedoms of citizens, national concord, assistance in the protection of law order and public safety;

17 Конституція України: Закон України від 28.06.1996 р. № 254к/96-ВР. Дата оновлення: 21.02.2019 p. URL: http://zakon2.rada.gov.ua/laws/show/254к/96-вр. 
8) Ensuring the functioning and development of state and national languages and cultures in the ARC; protection and use of historical monuments;

9) Participation in the development and implementation of state programs for the return of deported people;

10) Initiation of introduction of a state of emergency and establishment of areas of emergency ecological situation in the ARC or in its separate areas.

In accordance with the laws of Ukraine other powers can be delegated to the Autonomous Republic of Crimea ${ }^{18}$.

Article 139 of the Constitution of Ukraine provides for operation of the Representative Office of the President of Ukraine in the ARC, the status of which is determined by the relevant law of Ukraine ${ }^{19}$.

The constitutional and legal regulation of the temporarily occupied territories of Ukraine is a set of constitutional norms enshrined in the legal acts defining the legal status and regime of the temporarily occupied territories, as well as the scope of human rights and freedoms at the temporarily occupied territories.

\section{The Ways of Improvement of Ukrainian Legislation in the Part of Provision of Human Rights and Freedoms at the Temporarily Occupied Territories of Ukraine}

Analyzing the constitutional law science, we can see the gap between theoretical studies of the constitutional human and civil rights and freedoms at temporarily occupied territories and the needs of legal practice, inability of scientists to formulate substantiated conclusions and proposals in the near future, that is why it is necessary to comprehensively combine scientific achievements in the field of research.

In the Basic Law of Ukraine there is no concept of temporarily occupied territories, and the science of constitutional law does not define the concept of "constitutional and legal regulation of temporarily occupied territories". Therefore, taking into account the relevance of this problem, we consider it necessary to define these concepts.

\footnotetext{
18 Конституція України: Закон України від 28.06.1996 р. № 254к/96-ВР. Дата оновлення: 21.02.2019 p. URL: http://zakon2.rada.gov.ua/laws/show/254к/96-вр.

19 Конституція України: Закон України від 28.06.1996 р. № 254к/96-ВР. Дата оновлення: 21.02.2019 p. URL: http://zakon2.rada.gov.ua/laws/show/254к/96-вр.
} 
Therefore, the temporarily occupied territories of Ukraine are an integral part of Ukrainian territory, defined by the Constitution of Ukraine, which is subject to the Constitution and laws of Ukraine in accordance with international law ratified by Ukraine.

Although at the end of $20^{\text {th }}$ century and at the beginning of the $21^{\text {st }}$ century Ukrainian theorists, constitutionalists and specialists of other branches of law studied and are still studying the human and civil rights and freedoms, it remains the urgent issue: the provision of human rights at the temporarily occupied territories, the restoration of territorial value. Therefore, an advisory body should be set up under the President of Ukraine - the Commission on ensuring human rights at the temporarily occupied territories and restoring the territorial integrity of Ukraine.

According to the aim and role of the Commission activities it would be possible to include the following in its main tasks:

1) Assisting the President of Ukraine in approving the ideas of ensuring human rights at the temporarily occupied territories and restoring territorial integrity;

2) Preparing and drafting proposals on normative legal protection of human rights at temporarily occupied territories and restoration of territorial integrity for the President of Ukraine;

3) Advisory, informational, expert-analytical and other support of the activities of the President of Ukraine for ensuring human rights at the temporarily occupied territories and restoration of territorial integrity;

4) Cooperation with research institutions and higher educational institutions, in particular, on conducting research and analytical studies on the problems of ensuring human rights at the temporarily occupied territories and restoring territorial integrity; and consultations and preparation of proposals on the above issues; ensuring interaction between public authorities, local self-government bodies and non-governmental organizations whose activities are aimed at ensuring the human and civil rights and freedoms at temporarily occupied territories and restoration of territorial integrity;

5) Preparation of expert opinions on the laws adopted by the Verkhovna Rada of Ukraine under the instructions of the President of Ukraine, and submitted to him for signature, with respect to observance of provisions of ensuring human rights at the temporarily occupied territories and restoration of territorial integrity; 
6) Monitoring of legislative, administrative and judicial practice in the field of ensuring human rights at the temporarily occupied territories and restoration of territorial integrity, etc.;

7) Preparation of proposals for the development of international cooperation in the field of human rights protection at the temporarily occupied territories and restoration of territorial integrity, generalization and promotion of dissemination of national and international experience on these issues, promotion of implementation of international programs and projects in Ukraine on the issues of ensuring human rights at the temporarily occupied territories and restoration of territorial integrity;

8) Conducting and participating in the work of conferences, seminars, public hearings on the issues of generalization and introduction into practice of better national and international experience in solving problems in the field of human rights protection at temporarily occupied territories and restoration of territorial integrity, etc.

In order to fulfill the tasks entrusted to the Commission for ensuring human rights at the temporarily occupied territories and restoration of territorial integrity of Ukraine, it should be entitled to receive information, documents and materials from the state and local self-government bodies on the issues of ensuring human rights at the temporarily occupied territories and restoration of territorial integrity; to create working groups, commissions, convene meetings on issues within its competence; to involve employees of central and local executive bodies, institutions, organizations (with the consent of their leaders) to consider issues within its competence; to involve scientists, experts and specialists in the study of certain issues, execution of works and tasks, including on a contractual basis; to carry out publishing activities.

On the one hand, deputies, representatives of public authorities (law enforcement, human rights activists, etc.), could enter the Commission on ensuring of human rights at the temporarily occupied territories and restoration of territorial integrity of Ukraine, on the other hand - wellknown scientists and representatives of the public.

After its creation, in the course of performing the tasks assigned to it, the Commission on ensuring human rights at the temporarily occupied territories and restoration of territorial integrity of Ukraine will, under the established procedure, interact with the APU, as well as consultative, advisory and other subsidiary bodies and services created by the President 
of Ukraine, with the apparatus of the VRU, The Secretariat of the Cabinet of Ministers of Ukraine, central and local executive authorities, local selfgovernment bodies, their associations, public organizations, international institutions, etc.

\section{CONCLUSIONS}

Since the very beginning of civilization a person has tried to assert own rights, protect and renew them in case of violation. A struggle for new territories has begun with the emergence of statehood and establishment of country borders, and it is still taking place. To that end, we can state that a war has been the most significant form of relations between people for a long time. As a result of such struggle, unlawful seizure of the territories of one state by another state often takes place, occupation respectively and, as a rule, annexation. Therefore, the rights of people, who found themselves at the occupied territories after the invasion, required a special protection.

One of the reasons, having led to emergence of wars and conflicts during all human history, has been and is still the issue of countries' territories, as well as their borders which is integral attribute of sovereignty of any state.

The constitutional and legal regulation of the temporarily occupied territories of Ukraine is an essential issue for our state under the hybrid war conditions, triggered by the Russian Federation. This is why Ukraine is trying to restore its territorial integrity independently and with the assistance of international support.

At present, the status of the temporarily occupied territories of Ukraine is specific. In this regard, the issues of human rights in these areas acquired a specific nature. It is certainly that due to unlawful actions of the Russian Federation the part of the state territory of Ukraine has found itself under the aggressor country occupation. In accordance with Article 22 of the Constitution of our state, the human and civil rights and freedoms enshrined therein are not exhaustive, constitutional rights and freedoms are guaranteed and can not be cancelled. The part of this article emphasizes that when new laws are adopted or when amendments are made to them, it is not allowed narrowing the content and scope of existing rights and freedoms. The Constitution of Ukraine declares that the establishing and ensuring human rights and freedoms is a main duty of 
the state. The observance of human rights is a main goal of relations between the state and a citizen, and free and effective exercise of human rights is one of the most important features of a democratic society and a law-governed state. The relations between state institutions and citizens must guarantee both real observance of rights and freedoms belonging to the citizen, as well as reliable legal protection in case of their violations, which finds its embodiment in the legal status of a person and a citizen. However, today the Ukrainian state is in an extremely vulnerable situation, since it is deprived of the opportunity to control the occupied territories, and, accordingly, to implement the norms of the Constitution of Ukraine into life.

There is no concept of the temporarily occupied territories in the Constitution of Ukraine, and the science of constitutional law does not define the concept of "constitutional legal regulation of the temporarily occupied territories of Ukraine". Due to the relevance of this issue today, it is considered to be necessary to give the definition of this concept.

Thus, the temporarily occupied territories of Ukraine are an integral part of Ukrainian territory, defined by the Constitution of Ukraine, which is subject to the Constitution and laws of Ukraine in accordance with the norms of international law ratified by the Verkhovna Rada of Ukraine.

The constitutional and legal regulation of the temporarily occupied territories of Ukraine is a set of constitutional norms enshrined in the legal acts defining the legal status and regime of temporarily occupied territories, as well as the scope of human rights and freedoms at the temporarily occupied territories.

\section{REFERENCES}

1. Правова система України: історія, стан та перспективи : у 5 т. Х. : Право, 2008. Т. 2 : Конституційні засади правової системи України і проблеми її вдосконалення / за заг. ред. Ю. П. Битяка. Х. : Право, 2008. 576 с.

2. Рудницький С. Л. Українська справа зі становища політичної географії. Берлін: Укр. Слово, 1923. 282 с.

3. Купрієнко Д. А., Дем'янюк Ю. А., Діденко О. В. Державна територія і державний кордон: навчальний посібник. Хмельницький: Видавництво НАДПСУ, 2014. 256 с. 
4. Про забезпечення прав і свобод громадян та правовий режим на тимчасово окупованій території України: Закон України від 27.04.2014 p. № 1207-VII. Дата оновлення: 04.11.2018 p. URL: https://zakon.rada.gov.ua/laws/show/1207-vii

5. Конституція України: Закон України від 28.06.1996 p. № 254к/96-BP. Дата оновлення: 21.02.2019 p. URL: http://zakon2.rada.gov.ua/laws/show/254к/96-вр.

\section{Information about the author:} Iliashko O. O.

Candidate of Juridical Sciences, Assistant Professor at the Department of Constitutional and International Law of the Educational-Scientific Humanitarian Institute of the V. I. Vernadsky Taurida National University 33, Ivana Kudri str., Kyiv, Ukraine 